\title{
THE CHARTERS OF IVAN IV (THE TERRIBLE) TO THE HILANDAR AND RILA MONASTERIES ${ }^{1}$
}

\begin{abstract}
:
The paper examines letters patent and edict charters granted by the Russian Tsar Ivan IV (the Terrible) to the Serbian Hilandar community of monks at Athos and Rila monastery in Bulgaria. The majority of the sources were lost over time and they are available only in copies from the so-called Ambassadorial book of 1517-71 or in copies from the 17th century. The letters patent of Ivan IV (original and the so-called "wordfor-word copy") to Hilandar monastery are unique. They confirm its right to have its own metochion in Kitai-gorod near the Kremlin. The edict charters to the community of monks are of special interest, as they allowed the right of tax-free and unchecked passage through Russian territory together with the privilege of collecting donations.
\end{abstract}

Keywords:

Hilandar Monastery, Rila Monastery, Ivan IV the Terrible, letters patent, edict charters, Ktitoria.

АнНОТаЦия: А.С. ДОБЫчИНА. «ГРАМОТЫ ИВАНА ГРОЗНОГО ХИЛАНДАРСКОМУ И РИЛЬСКОМУ МОНАСТЫРЯМ».

В статье рассмотрены жалованные и указные грамоты, выданные русским царем Иваном IV сербскому Хиландарскому монастырю на Афоне и Рильскому в болгарских землях. Бо́льшая часть источников была утеряна со временем и дошла лишь в копиях из т.н. Посольской книги за 1517-71 гг. или списках XVII в. Уникальность представляют жалованные грамоты (оригинал и «дословная копия») Ивана Грозного Хиландарскому монастырю. Они подтверждали его право на подворье в Китай-городе близ Кремля. Интерес представляют и указные грамоты монахам, дававшие им право свободного и беспошлинного проезда по территории России с правом сбора милостыни.

\section{Ключевые слова:}

Хиландарский монастырь, Рильский монастырь, Иван IV Грозный, жалованные грамоты, указные грамоты, ктиторство.

The charters that the Russian Tsar Ivan the Terrible (1530-84) granted
to Serbian Hilandar monastery on Mount Athos and the Rila monastery in the Bulgarian lands are valuable sources for research on the history of relations between the Southern Slavs and Russia in the 16th century. On the one hand, it is well known that the 16th century was the time of the Ottoman Empire's "Magnificent Century", and where both of the aforementioned monasteries were located. On the other hand, it was also a period when the Empire started

1 The work was carried out with the financial support of the RFBR (grant № 18-512-76004). 
to decline. Even during the lifetime of the Sultan Suleyman I (1520-66), the Orthodox monasteries, including those on Mt. Athos, faced serious financial difficulties, and under the rule of his son, Selim II (1566-74), the practice of seizing their property began.

The Ottoman authorities' arbitrary treatment created an atmosphere in which, in the 1550s, the Hilandar and Rila monasteries almost simultaneously turned for help to the Moscow state, which had grown in strength and which in the 16th century had attracted the attention of representatives of all of the Ottoman Empire's major Orthodox communities. The coronation in 1547 of the young Grand Prince, Ivan IV Vasilyevich, marked a new milestone in the development of the ideology, "Moscow, the Third Rome." It affirmed Rus-

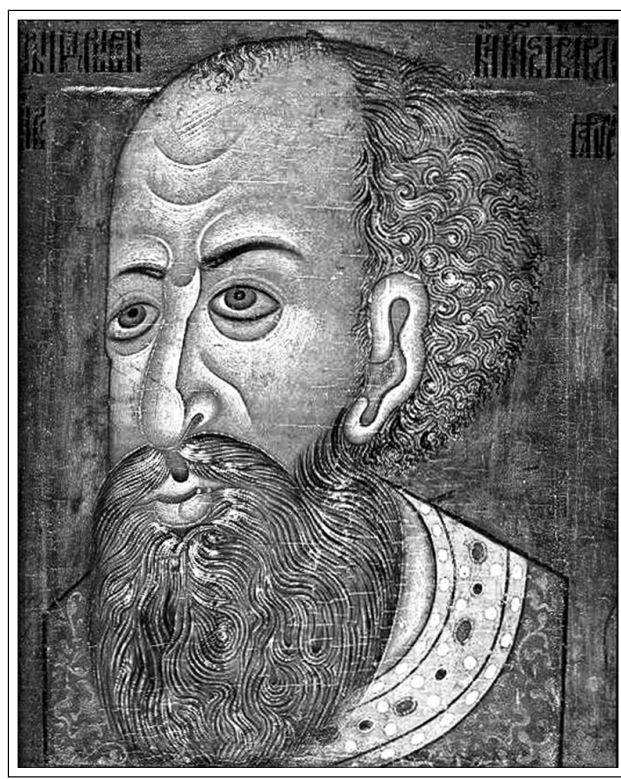

Ivan IV the Terrible, old painted portrait

(parsuna) sia's unique status as the successor of the Byzantine Empire and the defender of the interests of all orthodox believers. The Russian Tsar's triumphant victory in 1552 over the "fragment of the Golden Horde", the Kazan Khanate, contributed to strengthening Moscow's authority and became a symbol of Christians' successful struggle against the "godless" Muslim enemy.

The Serbian Hilandar monastery on Mt. Athos was the recipient of special attention by Ivan IV. Blood ties played a significant role in this: the Russian autocrat was related to the Serbian rulers on both the side of his grandmother, the Byzantine Princess Sofia Palaiologina, and that of his mother, Princess Helena Glinskaya. Protection of the Serbian Tsar's Hilandar Monastery was supposed to legitimize Ivan IV's new title and to increase the international prestige of Moscow, as well as to strengthen the position of the newly-minted Tsar within the country. It is no coincidence that the titles of the Russian autocrat and certain formulas in his charters were partially borrowed from the acts of Serbian Tsar Stefan Dushan (1346-55), who was a donator at Hilandar.

Who actually initiated establishing regular contacts between Moscow and the Hilandar monastery is still a matter of conjecture. A letter from the Serbian monks in 1550 reveals that they received a certain document written by Ivan IV expressing his desire to be a churchwarden of the monastery, but this document has not been preserved. In 1555 Hilandar officially accepted the Tsar's protection and was proclaimed "a second pilgrimage site," after the "first one": the Russian Panteleimon monastery on Mt. Athos. The abbot of the monastery, Paisius, 
who arrived in Moscow, presented sacred objects to the Tsar, which were very important to the Serbs: the cross worn by St Sava of Serbia and the relics of the Proto-martyr Stephen, the heavenly patron of the Serbian Nemanich dynasty. In response, in February 1557 the monastery received significant monetary donations from Ivan IV and his brother George, as well as a richly decorated curtain for the royal doors: the "catapetasm" (from the Greek $\kappa \alpha \tau \alpha \pi \varepsilon ́ \tau \alpha \sigma \mu \alpha$ - "curtain"), a special curtain usually placed behind the iconostasis, separating the royal doors and the altar throne.

Beginning in the 1550s the abbots and monks of Hilandar were frequent guests at the Moscow court and regularly received letters patent (charters) from the tsar, the so-called "chrysobulls" (from the Greek $\chi \rho v \sigma o ́ \beta o v \lambda \lambda o v$ - golden seal), as well as edict (or "travel") charters granting them the right of tax-free and unchecked passage through Russian territory together with the privilege of collecting donations. The texts of these documents are available in the Ambassadorial Book of 1517-71, located in the Russian State Archive of Ancient Acts. Most of these documents are not preserved in the original - only the aforementioned Ambassadorial Book allows us to judge their nature and content. Thanks to these records, it is known that Ivan the Terrible did not skimp on generous gifts to the monastery and regularly bestowed upon it substantial sums of money, furs, richly decorated precious church utensils and icons. Along with these "material" gifts, the monastery also received "spiritual" gifts - unique religious books intended for translation into Serbian.

The monastery was able to receive not just movable property as gifts but also some lands. Thus, in March 1556, the Tsar issued a letters patent granting the Hilandar monastery the exclusive right to own a metochion in Kitai-gorod on Nikolskaya Street near the Kremlin. The original of this document has been lost, but the monastery's archive has preserved the original of another, dated 1571, confirming the Hilandar monastery's right of ownership of the metochion at the same place.

The document is available in two copies: the original, and so-called "verbatim copy." Both are on parchment; the text is written in the cursive of the 16th century. As a chrysobull, the document has a rich design: a headpiece, a field decoration with a picture of a flower in the upper part of the left field, initials executed in gold and bright colors. The first word in the charter, "Tsar," is decorated in the form of a monogram. In the middle of the lower margin of the charter there were traces of a silk red cord attached to it. A gilded round seal is preserved separately from the document. On its front side there is a horseman striking a dragon with a spear and the inscription: "By the Grace of God, the Tsar and Grand Prince Ivan Vasilyevich of All Russia." On the reverse side there is a double-headed eagle with two crowns; the inscription reads: "Vladimir, Moscow, Novgorod Tsar of Kazan and Astrakhan." The "verbatim copy" of the charter is more modestly decorated: only the letters of the first line are ornamented. A red cord with a seal attached to it has also survived (unfortunately, the seal has been lost). 
For the most part, the originals of Ivan IV's decrees, which regulated the Hilandar monks` movement around the country, have also been lost. The archive of the monastery has preserved the original of only one parchment "travel" charter of July 1556, which granted to Serbian monks the right of tax-free and unchecked passage through Russian territory, together with the privilege of collecting alms. Compared with the letters patent, the document has a modest design: it does not have any decorations, colored ink was not used, and the seal attached to the act has been lost.

The originals of Ivan IV's grants and decrees to the Bulgarian Rila Monastery (one of the largest centers of Orthodoxy in the Balkans and under the Tsar's special patronage) did not reach us. The attention the Russian ruler paid to the monastery was closely connected to the name he (Ivan the Terrible) shared with the founder of the community, St John (Ivan) of Rila.

It is well-known that the Rila monastery had strong, long-standing ties to the Russian St Panteleimon monastery on Mt. Athos, as evidenced by a contractual charter between them dated 1466. Close ties were obviously maintained between the Rila and Hilandar monasteries: it was at the Hilandar metochion in Kitai Gorod that the Rila monks stayed during their visits to Moscow. Based on a letter of the Rila elders to Tsar Mikhail Fyodorovich Romanov (1613-45), we know that the monastery had chrysobullon letters patent from Ivan IV at its disposal. However, as the visiting monks themselves once complained to the Tsar, "the Tsar's writings sank in the Danube River for our sins."

Among copies from the 17th century, two edict charters have been preserved. They were granted to the Rila monks in 1558. One of them is dated November 1, 1558 and was given to the visitors from Rila: priest Joseph, deacon Cyril and the elder Eugene. In it the Tsar grants them duty-free passage and the right to collect alms in the lands to the north and northeast of Moscow. A December edict charter of the same year is addressed to coachmen on the road from Moscow to Smolensk and the Lithuanian border. It calls for providing transport and guides to the former abbot of the Rila monastery, Gregory, and accompanying monks from the monastery.

The letters patent and edict charters of Ivan IV granted to the two monasteries, the Serbian Hilandar on Mt. Athos and the Rila in the Bulgarian lands, are one-of-a-kind sources. They allow us to form a view of the active inter-Slavic Orthodox connections in the 16th century and Russia's role in their preservation and development. Despite the loss of most of the original documents, they continue to attract the close attention of researchers, as they have great potential for further study of this issue. 


\section{BIBLIOGRAPHY}

Čencova V.G. Ktitorstvo i carskij titul: Rossiya i Hilandarskij monastyr' v XVI veke // Slavyanovedenie. 2014. №2. S. 15-24.

Dylevskij N.M. Ryl'skij monastyr' i Rossiya v XVI i XVII veke. Sofia, 1946.

Horoškevič A.L. Rossiya v sisteme meždunarodnyh otnošenij serediny XVI veka. Moskva, 2003.

Ihchiev D. Turskite dokumenti na Rilskiya monastir. Sofia, 1910.

Ivanov Y. Sveti Ivan Rilski i negoviyat monastir. Sofia, 1917.

Kaštanov S.M. Istočniki o vzaimootnošeniâh meždu Rossiej i grečeskim pravoslavnym mirom v XVI veke (čast' I) // Arheografičeskij ežegodnik za 2012 god. Moskva, 2016. S. 22-47.

Kisterev S.N. Ivan Groznyj i hilandarskij ekklisiarh Grigorij // Kapterevskie čtenia. Sbornik statej. Vyp. 9. Moskva, 2011. S. 26-35.

Murav'ev A.N. Snošenia Rossii s Vostokom po delam cerkovnym. Sankt-Peterburg, 1858.

Rossiya i grečeskij mir v XVI veke. Moskva, 2004.

Rusiya, Aton i Rilskiyat manastir (XI - nachaloto na XX v.). Sbornik dokumenti. Sofia, 2016.

Snegarov I. Kulturni i politicheski vrazki mezhdu Balgariya i Rusiya prez XVI-XVIII v. Sofia, 1953.

Tikhomirov M.N. Istoričeskie svyazi Rossii so slavyanskimi stranami i Vizantiej. Moskva, 1969.

Želtov M.S., Maksimovič KA., Mubin V.S., Romanenko E.V, Statis G., Turilov A.A. i dr. Afon // Pravoslavnaya ènciklopediya. T. 4. Moskva, 2002. S. 103-81.

\section{ILLUSTRATIONS}

1. Rila Monastery in Bulgaria.

2. Hilandar Monastery on Athos, Greece.

3. The initial sheet of Ivan IV 's letters patent to the Hilandar Monastery. 1571.

4. Fragment of Ivan IV's letters patent to the Hilandar Monastery, 1571.

5. Fragment of Embassadorial Book No. 1, containing information about the letters patent and edict charters of Ivan IV to the Orthodox centers in the Ottoman Empire.

6. Fragment of Embassadorial Book No. 1, containing information about the letters patent and edtct charters of Ivan IV to the Orthodox centers in the Ottoman Empire.

7. Ivan IV the Terrible. Old painted portrait (parsuna).

8. Katapetasma (an offering of Ivan IV to the Hilandar Monastery).

9. The Nicolo-Greek Monastery near the Kremlin, where the historic Hilandar sub-church was located.

10. Cover of the work of the scholar A.N. Muravyov, who first made known some of Ivan IV's letters patent and edict charters to the Orthodox centers in the Ottoman Empire. 